\title{
The Southeast Colorado PE Academy: Implementation and Outcomes in Rural Elementary Schools, 2014-16
}

\author{
Nicole J. Smith1, Elaine S. Belansky², Nicholas Cutforth ${ }^{2}$ \\ ${ }^{1}$ Department of Kinesiology, California State University, Fresno, Fresno, USA \\ ${ }^{2}$ Morgridge College of Education, University of Denver, Denver, USA \\ Email: njsmith@csufresno.edu
}

How to cite this paper: Smith, N. J., Belansky, E. S., \& Cutforth, N. (2020). The Southeast Colorado PE Academy: Implementation and Outcomes in Rural Elementary Schools, 2014-16. Advances in Physical Education, 10, 436-458. https://doi.org/10.4236/ape.2020.104035

Received: July 25, 2020

Accepted: November 16, 2020

Published: November 19, 2020

Copyright $\odot 2020$ by author(s) and Scientific Research Publishing Inc. This work is licensed under the Creative Commons Attribution International License (CC BY 4.0).

http://creativecommons.org/licenses/by/4.0/

\begin{abstract}
This paper describes the implementation and outcomes of the Southeast Colorado Physical Education Academy (SECPEA). The SECPEA intervention aimed to improve the quality of physical education taught by 21 teachers in 19 rural schools in Southeast Colorado over a two-year period by supporting the implementation of an enhanced physical education program (EPE). The System for Observing Fitness Instruction Time was used to evaluate the effectiveness of the intervention at baseline, post year one, and post year two. Post year one, a moderate and significant increase was observed in overall MVPA\% per lesson. The largest increase was observed in the MVPA\% during the first five minutes of lessons. Significant increases were also observed in girls' MVPA\% and for teacher promotion of MVPA. Post year two, significant positive increases were observed in the percentage of vigorous physical activity and energy expenditure rate. The SECPEA was a successful model for implementation of an EPE. Continued testing of the model in diverse settings is warranted.
\end{abstract}

\section{Keywords}

Moderate to Vigorous Physical Activity (MVPA), Enhanced Physical Education (EPE), Rural Schools, Obesity Prevention, Professional Development, Implementation Science

\section{Introduction}

Prevention of childhood obesity is an important public health priority. The prevalence of obese children increased from $4 \%$ to $18 \%$ worldwide since 1975 (WHO, 2018a), and currently nearly $20 \%$ of the United States (U.S.) children 
and adolescents ages 6 - 19 are obese (Hales et al., 2017). The consequences of childhood obesity are severe and well-documented. Obese children and adolescents are more likely to report low self-esteem (Strauss, 2000) and poor body image (Harringer \& Thompson, 2012), and are at greater risk for Type II diabetes and obesity in adulthood (Gordon-Larsen et al., 2010).

According to a meta-analysis by Johnson and Johnson (2015), childhood obesity is more common among children living in rural communities compared to children from metropolitan regions. In a research brief from 2012, approximately one quarter of all Americans living in poverty were from rural communities (Housing Assistance Council, 2012). The prevalence of childhood obesity in rural communities is influenced by a myriad of socio-ecological factors. Children from rural communities are often characterized as "food insecure" because there is no supermarket within 10 miles of their home (Ver Ploeg et al., 2012) and families often rely on convenient sources of fast food that contribute to obesogenic conditions when consumed regularly. Additionally, it is common for children from rural communities to have limited access to physical activity opportunities (e.g., lack of access to public parks, active transportation pathways, lack of street lighting; Warren, Beck, \& Delgado, 2019). Given these realities, it should not be surprising that rural children and adults are at greater risk for obesity than their urban counterparts (Johnson \& Johnson, 2015).

Rural schools can play an important role in the prevention of childhood obesity (Belansky et al., 2013). Further, scientists agree that physical activity is an important part of the solution and suggest that schools should offer a variety of physical activity programs before, during, and after school, including physical education (IOM, 2013; USDHHS, 2018; UNESCO, 2015; WHO, 2018b). The aims of physical education relate to physical activity, motor skill development, physical fitness, and promotion of healthy and active lifestyles. While numerous curricular models are available in the U.S., enhanced physical education (EPE) programs are the only curricular model with strong evidence for increasing health-enhancing moderate to vigorous physical activity (MVPA) (Community Preventive Services Task Force, 2014; Lonsdale et al., 2013).

Since the onset of the obesity crisis in the 1980's, a number of EPE programs have demonstrated effectiveness in rigorous randomized control trials (Lonsdale et al., 2013). Of these programs, Sports, Play, and Active Recreation for Kids (SPARK) is well-known for increasing MVPA (Sallis et al., 1997; McKenzie et al., 2004) improving physical fitness (Sallis et al., 1997), improving motor skill proficiency (McKenzie et al., 1998), and increasing student enjoyment in physical education (McKenzie et al., 1994; Prochaska et al., 2003).

Given the emergence of effective EPE programs, now the challenge is in finding ways to promote widespread adoption and implementation in a variety of settings, including in rural schools. The San Luis Valley PE Academy (SLVPEA) is an example of a successful model to disseminate an EPE program in rural schools (Belansky et al., 2016). The SLVPEA was implemented in a rural, high 
poverty region from 2011-2013 as part of the Healthy Eaters, Lifelong Movers (HELM) project. HELM was comprised of two main components including Assess-Identify-Make it Happen (AIM) and the SLVPEA. While AIM was an evidence-based intervention for realizing environmental and policy changes to increase physical activity and healthy eating in schools (Belansky et al., 2013), the primary goal of the SLVPEA was to improve the quality of physical education in participating schools by supporting the successful implementation of an EPE program. The SLVPEA resulted in significant gains in MVPA\% and improvements in time devoted to fitness, skill practice, and time management in physical education (Belansky et al., 2016).

While the SLVPEA demonstrated effectiveness, it was only tested in one rural region. McKenzie and colleagues (2016) have suggested that what works in one region may not work in another. Thus, more research is needed to assess the effectiveness of models like the SLVPEA in other contexts that differ in regards to ethnicity, geography, extent to which districts share resources, and access to physical activity opportunities outside of schools.

From 2014-16, researchers implemented HELM in Southeast Colorado including AIM and the PE Academy components. Similar to the SLVPEA, the primary aim of the Southeast Colorado PE Academy (SECPEA) was to improve the quality of physical education in the region by attempting to replicate the SLVPEA. The intent was to implement the same components (i.e., SPARK curricular resources, equipment, professional development workshops, and site support) as the SLVPEA, but with some modifications to accommodate implementation in a much larger, decentralized geographic region with different teachers in different schools and by different personnel (i.e., different perspectives and expertise). The purpose of this paper is to describe the implementation of the SECPEA and the extent to which the SECPEA led to improvements in the quality of physical education post year one and post year two. The study was guided by the following research questions:

1) To what extent did the SECPEA lead to increased MVPA\% and higher quality instruction (i.e., changes in lesson context \% and teacher promotion of MVPA) post year one?

2) To what extent did the second year of the SECPEA lead to additional changes in MVPA, lesson contexts, and teacher promotion of MVPA?

\section{Methods}

The study protocol and Memorandum of Understanding (MOU) were approved by the Colorado Multiple Institutional Review Board.

\subsection{Research Design}

A pre-post-post within teachers design was used to evaluate the effectiveness of the SECPEA. Data were collected at baseline (Spring 2014), post year one (Spring 2015), and post year two (Spring 2016). 


\subsection{Eligibility and Recruiting}

All public schools in the region that offered grades K-6 were eligible to participate in HELM (i.e., the SECPEA and AIM). Recruiting was accomplished via phone or email. Schools could choose to participate in the SECPEA and AIM components simultaneously or could choose to participate in one component or the other as a stand-alone intervention. Principals were presented with a detailed Memorandum of Understanding (MOU) to explain the goals, expectations, and benefits of participation. Schools that agreed to participate in the SECPEA were provided with SPARK curricular resources, equipment for implementing SPARK, professional development, and site support from a trained master teacher up to two times per month. Physical education teachers agreed to implement SPARK in at least one grade level in year one and at least one additional grade level in year two. They also agreed to attend four two-day SPARK workshops over the two-year period and additional SPARK booster sessions and workshops to support implementation of SPARK and physical education curriculum enhancements in their school. Principals were encouraged to attend professional development workshops and agreed to meet with master teachers monthly. Lastly, schools agreed to participate in annual data collection including completing principal and teacher surveys and allowing observations of physical education lessons.

\subsection{Setting and Participants}

Table 1 describes the characteristics of the 21 teachers who completed surveys and had at least baseline and post year one data. The teachers were from 19 schools located in 18 school districts in a region comprised of eight different counties covering approximately $41,352 \mathrm{~km}^{2}$. The average school enrollment was 466 students (Range $=28-1,453$ ) with $38 \%$ Hispanic non-white students, and

Table 1. Elementary school PE teacher characteristics, 2014-16a.

\begin{tabular}{|c|c|c|c|}
\hline Teacher Characteristic & Mean & SD & $\mathbf{N}$ \\
\hline Total years teaching Physical Education & 13.7 & 9.2 & 21 \\
\hline $\begin{array}{l}\text { Number of responsibilities at school, } \\
\text { including teaching Physical Education }\end{array}$ & 3.0 & 0.9 & 20 \\
\hline$\%$ of the day spent teaching elementary Physical Education & 54.2 & 27.4 & 20 \\
\hline Number of K-12 grades teaching Physical Education & 6.8 & 3.2 & 21 \\
\hline & \multicolumn{2}{|c|}{ \% Frequency } & $\mathbf{N}$ \\
\hline$\%$ PE certified & \multicolumn{2}{|c|}{$70.0 \%$} & 20 \\
\hline$\%$ Female & \multicolumn{2}{|c|}{$42.9 \%$} & 21 \\
\hline \% Master's Degree & \multicolumn{2}{|c|}{25.0} & 20 \\
\hline$\%$ Member of SHAPE Colorado Society of Health and Physical Educators ${ }^{\mathrm{b}}$ & \multicolumn{2}{|c|}{$0 \%$} & 21 \\
\hline
\end{tabular}

Note: ${ }^{a}$ Data are presented for teachers with baseline PE teacher survey data and baseline and post year 1 SOFIT data. ${ }^{b}$ Formerly the Colorado Alliance for Health, Physical Education, Recreation, and Dance. 
$64 \%$ of students participating in free and reduced meal programs. Ten of the schools offered lower and upper primary grades (e.g., PK-6th grade), five offered lower primary grades (PK-2nd grade) or upper primary grades (3 - 6th grade), one school offered PK-8th grades, and three schools offered grades K-12.

\subsection{PE Academy Intervention}

Table 2 describes the timeline for major milestones of the SECPEA according to the four stages of diffusion (i.e., dissemination, adoption, implementation, and institutionalization).

A community-based participatory approach was used to build relationships, grow support for the project, and shape the SECPEA (Israel et al., 2010). Awareness raising began in early spring 2014 when key stakeholders were invited

Table 2. SECPEA timeline of major milestones by stage of diffusion.

\begin{tabular}{|c|c|}
\hline Timeline & Disseminate-Awareness Raise \\
\hline Spring 2014 & $\begin{array}{l}\text { - Identify and build relationships with regional key stakeholders } \\
\text { - Invite regional key stakeholders to attend an initial planning meeting to } \\
\text { raise awareness about the effectiveness of EPE programs and how the PE } \\
\text { Academy model supports EPE programs. Ask for their input to inform } \\
\text { planning, recruiting, implementation, and evaluation of the SECPEA } \\
\text { - Invite key stakeholders to serve on the HELM Steering Committee }\end{array}$ \\
\hline & Adopt-Commit \\
\hline \multirow[t]{2}{*}{$\begin{array}{l}\text { Spring } 2014 \\
\text { to } \\
\text { Summer } 2014\end{array}$} & $\begin{array}{l}\text { - Recruit school principals and physical education teachers by raising } \\
\text { awareness about EPE and the value added by the PE Academy } \\
\text { (i.e., SPARK curricular resources, equipment, professional development } \\
\text { workshops, site support from a site coordinator) } \\
\text { - Review the Memorandum of Understanding (MOU) to define the } \\
\text { PE Academy deliverables and convey expectations for engagement } \\
\text { - Plan logistics related to curricular resources, equipment, workshops, } \\
\text { and site visits in the fall } \\
\text { Order curricular resources and equipment so schools receive packages } \\
\text { prior to the start of the SECPEA intervention }\end{array}$ \\
\hline & Implement-Engage \\
\hline $\begin{array}{l}\text { Fall } 2014 \\
\text { to } \\
\text { Spring } 2015\end{array}$ & $\begin{array}{l}\text { Two master teachers... } \\
\text { - Conduct "Happy Visits" to establish relationships with principals } \\
\text { - } \text { and physical education teachers } \\
\text { - } \quad \text { Engage in site support visits to physical education teachers } \\
\text { - } \quad \text { Conduct professional development workshops led by Elite SPARK trainers } \\
\text { - } \quad \text { Meet with principals to advocate for quality PE }\end{array}$ \\
\hline \multirow[t]{2}{*}{$\begin{array}{l}\text { Fall } 2015 \\
\text { to } \\
\text { Spring } 2016\end{array}$} & $\begin{array}{l}\text { One master teacher... } \\
\text { - } \quad \text { Engage in site support visits to physical education teachers } \\
\text { - } \quad \text { Professional development workshops (led by Elite SPARK trainer) }\end{array}$ \\
\hline & Institutionalize-Sustain \\
\hline $\begin{array}{l}\text { Spring } 2016 \\
\text { to } \\
\text { Fall } 2017\end{array}$ & $\begin{array}{l}\text { - A cadre of wellness training specialists lead booster workshop related to } \\
\text { technology and best practices related to high quality physical education } \\
\text { - Two master teachers from SLVPEA receive SPARK Train the Trainer certi- } \\
\text { fication to build capacity for sustainability initiatives }\end{array}$ \\
\hline
\end{tabular}


to participate in an initial planning meeting. These stakeholders represented different levels of influence and included regional superintendents, principals, physical education teachers, school nurses, and public health practitioners. After the initial planning meeting, stakeholders were invited to participate on the HELM steering committee which met quarterly over the two-year project. The steering committee was instrumental in helping form positive and supportive relationships in the region and played an important advisory role related to implementation and evaluation of the SECPEA over the two-year period.

In year one (Fall 2014-Spring 2015), two master teachers provided site support to principals and physical education teachers. In year two (Fall 2015-Spring 2016), as we discuss later in the paper, site support was scaled back to one master teacher due to unexpected changes in personnel. In spring 2016, the focus of the project shifted to sustainability initiatives to build local capacity for professional development and allow teachers to take ownership over quality physical education in the region. Two sustainability strategies were used: in spring 2016, a cadre of wellness training specialists provided a workshop on instructional technology; and in fall 2017, two master physical education teachers from the original SLVPEA, who were certified as SPARK Regional Trainers, provided a booster session on SPARK PE.

\subsubsection{Rubric for High Quality Physical Education}

The original SLVPEA rubric for "High Quality Physical Education" which defined characteristics and indicators of high quality physical education was introduced to principals and teachers during the initial "happy visit" (Belansky et al., 2016). Master teachers referred to the rubric during subsequent site support visits with principals and physical education teachers. For the SECPEA, the original rubric was modified by splitting skill instruction and assessment into two distinct categories. Table 3 identifies the eight categories, lists the total number of indicators for each, and provides keywords for indicators of quality physical education by category.

\subsubsection{SPARK Curricular Resources and Equipment}

All SECPEA schools received the SPARK K-2 and 3 - 6 curricula including SPARK Folios and access to SPARK Family online resources. Schools also received sufficient equipment for implementing the complete SPARK curriculum. Equipment packages were distributed in sets of 12 and the total package per school was based on the largest class size offered with a limit of up to $36 \mathrm{stu}-$ dents. Including curricular resources, online access, and equipment the cost was approximately $\$ 5,500$ - $\$ 10,500$ per school and varied due to differences in class size among schools (average $=\$ 9,936$ per school; data not shown).

\subsubsection{Professional Development Workshops}

Four two-day SPARK workshops were offered in a centrally located facility in the region in September 2014, January 2015, September 2015, and September 2016. Each SPARK workshop was led by an Elite SPARK Trainer who modeled 
Table 3. The SECPEA rubric categories and indicator key words.

\begin{tabular}{|c|c|c|c|}
\hline Number & Category & $\begin{array}{l}\text { Total } \\
\text { Indicators }\end{array}$ & Indicator Key Words \\
\hline 1 & Planning & 8 & $\begin{array}{l}\text { Standards-based; Teaching and learning styles; } \\
\text { Differentiated; Modified; Progressive; Safe; Ready; } \\
\text { Warm up and cool-down; Instructional alignment }\end{array}$ \\
\hline 2 & Management & 6 & $\begin{array}{l}\text { Behavior; Expectations; Transitions; Grouping } \\
\text { strategies; Feedback; Modeling; Promotion of } \\
\text { physical activity }\end{array}$ \\
\hline 3 & Communication & 6 & $\begin{array}{l}\text { Specific; Clear; Modeling; Concise; Goal-oriented; } \\
\text { Cues; Observation-based; Constructive }\end{array}$ \\
\hline 4 & $\begin{array}{c}\text { Learning } \\
\text { Environment }\end{array}$ & 3 & Differentiation; Equitable; Inclusive \\
\hline 5 & Movement & 6 & $\begin{array}{l}\text { MVPA; Management strategies; Dynamic; } \\
\text { Integrated; Teacher promotion of MVPA }\end{array}$ \\
\hline 6 & Skill Instruction & 6 & $\begin{array}{l}\text { Skill development; Differentiated instruction; } \\
\text { Progressive; Challenging; Equitable; Cues; } \\
\text { Developmentally appropriate; Feedback }\end{array}$ \\
\hline 7 & Assessment & 7 & $\begin{array}{l}\text { Informed planning; Performance feedback; } \\
\text { Assessment driven goals; Formative assessment; } \\
\text { Summative assessment; Standards-based } \\
\text { assessment; Variety }\end{array}$ \\
\hline 8 & $\begin{array}{l}\text { Program and } \\
\text { Professional } \\
\text { Development }\end{array}$ & 6 & $\begin{array}{l}\text { Integration; Multi-disciplinary; Collaboration; } \\
\text { Advocacy; Resourcefulness; Involvement; } \\
\text { Engagement }\end{array}$ \\
\hline
\end{tabular}

SPARK pedagogical strategies and SPARK activities while the SECPEA teachers actively participated. During the workshops, teachers had opportunities to reflect and dialogue with the Elite SPARK Trainer and with one another to promote learning and professional growth.

Two additional professional development workshops were led by a cadre of wellness training specialists from the SLVPEA in year two. The topics of these workshops were related to instructional technology (Day 1) and highly effective physical education practices (Day 2). Teacher participation in all professional development workshops was supported by paying for substitute teachers and a one-night hotel stay for teachers traveling greater than 75 miles one way, and reimbursing mileage.

\subsubsection{Site Support}

In year one, two master teachers were hired to provide site support to the 21 teachers participating in the SECPEA. At the time of being hired, the master teachers held teaching positions in nearby schools. Both had master's level degrees, were up to date with current best practices, and had strong track records as effective physical education teachers. In year two, both master PE teachers left their positions and a third master teacher was hired to provide site support to all the PE teachers. This master PE teacher was a long-time resident of the community, retired, and well respected among coaches and PE teachers across the re- 
gion. While not steeped in the latest best practices, this master PE teacher showed capacity to forge trusting partnerships with PE teachers.

The goal of site support visits was to promote teachers' growth by supporting SPARK implementation, curriculum development, and application of pedagogical strategies associated with high quality physical education, and provide strategies to advocate for quality physical education (i.e., the link between physical activity and academic achievement). Master teachers accomplished this goal by helping teachers unpack the SPARK curriculum and equipment, observing teacher practices, and co-teaching and/or modeling best practices during visits. Master teachers observed one to three lessons per visit and met with the physical education teacher afterwards for a 30 - 45 minute reflective debrief conversation. Master teachers led with positive feedback and encouraged teachers to identify the lessons' strengths and opportunities for improvement. Teachers were encouraged to have a growth mindset, to take a leadership role in reflective conversations, and to set personal goals for improvement.

Table 4 lists the scope and sequence of site support meetings delivered by master teachers. In year one, the master teachers provided site support to every physical education teacher 8 - 9 times and met with every principal four times. Master teachers followed the scope and sequence in fall 2014 (i.e., visits 1 - 4); however, in spring 2015 they tailored the focus depending on the needs of each teacher. The tailored approach provided the master teacher with greater flexibility to make choices on the meeting content based on the progress of each teacher. Tailoring allowed master teachers to slow down with teachers who were less experienced and accelerate with teachers who were more experienced. In year two, teachers received 2 - 5 visits from one master teacher but no principal visits were held. The tailored approach was also utilized in year two.

\subsection{Data Collection: Outcome Measurement}

The System for Observing Fitness Instruction Time (SOFIT) was used to describe physical education lessons at baseline, post year one, and post year two. SOFIT assesses physical activity, lesson contexts, and teacher interactions during physical education lessons (McKenzie, 2015). SOFIT is frequently cited in studies of physical education and its utility, validity, and reliability are well documented in peer-reviewed studies conducted in the U.S. (McKenzie \& Smith, 2017) and international schools (Smith et al., 2019). A detailed protocol and standardized training videos are publicly available for no cost and explain the tool's utility and methods for conducting observations (McKenzie, 2015).

SOFIT is a systematic observation tool that uses momentary time sampling methods to simultaneously record physical activity levels (i.e., lying, sitting, standing, walking, vigorous), lesson context (i.e., management, knowledge, fitness, skill practice, game play, and other), and teacher promotion of MVPA (i.e., promotion "in" PE, promotion "out" of PE, or no promotion observed). Four students are randomly selected and observers are paced by an audio prompt at a 10 -seconds observe and 10-seconds record pace. The physical activity level of the 
Table 4. Scope and sequence of teacher and principal visits in the SECPEA, 2014-16.

\begin{tabular}{|c|c|c|}
\hline Mtg \# & Date & $\begin{array}{l}\text { Description [Rubric Category] } \\
\text { Topic(s) }\end{array}$ \\
\hline \multicolumn{3}{|c|}{ HAPPY VISIT (Teacher and Principal) } \\
\hline 1 & $\begin{array}{l}\text { Aug } \\
2014\end{array}$ & $\begin{array}{l}\text { "Happy Visit" } \\
\text { Relationship building, short term and long term goals; introduce SECPEA } \\
\text { rubric; unpack SPARK resources; workshop overview; Q \& A, logistics }\end{array}$ \\
\hline \multicolumn{3}{|c|}{ TEACHER VISITS } \\
\hline 2 & $\begin{array}{l}\text { Sept } \\
2014\end{array}$ & $\begin{array}{l}\text { Workshop Debrief } \\
\text { Workshop debrief; goal setting; trust building; set tone for growth } \\
\text { mindset and teacher engagement; demonstrate supportive approach; } \\
\text { share expectations for future visits }\end{array}$ \\
\hline 3 & $\begin{array}{c}\text { Oct } \\
2014\end{array}$ & $\begin{array}{l}\text { Focus on Planning [Category 1] } \\
\text { Recommended lesson structure: ASAP, clear goal, demonstration, } \\
\text { skill practice, challenge activity, cool-down, and closure }\end{array}$ \\
\hline 4 & $\begin{array}{l}\text { Nov } \\
2014\end{array}$ & $\begin{array}{l}\text { Focus on Planning \& Learning Environment [Categories } 1 \& 4 \text { ] } \\
\text { Short-term and long-term planning; standards-based instruction, } \\
\text { teaching styles, relevant content, instructional alignment; } \\
\text { differentiation of instruction; equipment and facilities }\end{array}$ \\
\hline 5 & $\begin{array}{c}\text { Dec } \\
2014\end{array}$ & $\begin{array}{l}\text { Focus on Management [Category 2] } \\
\text { Application of SPARK BASICS (boundaries, ASAP, signals, inclusion, } \\
\text { clear instruction, safety and supervision); grouping strategies, transitions }\end{array}$ \\
\hline 6 & $\begin{array}{c}\text { Feb } \\
2015\end{array}$ & $\begin{array}{l}\text { Focus on Communication [Category 3] } \\
\text { Clarity, voice, enthusiasm, clear goal, } 80 \text { - } 20 \text { Rule, cues, feedback, closure }\end{array}$ \\
\hline 7 & $\begin{array}{l}\text { Mar } \\
2015\end{array}$ & $\begin{array}{l}\text { Focus on Fitness and Learning Environment [Categories } 4 \text { \& 5] } \\
\text { ASAP, fitness disguised, promotion of MVPA goals, brief instruction, } \\
\text { inverted U, health-fitness tasks, skill fitness tasks, personalized goals }\end{array}$ \\
\hline 8 & $\begin{array}{c}\text { Apr } \\
2015\end{array}$ & $\begin{array}{l}\text { Focus on Skill Instruction [Category 6] } \\
\text { Task development, feedback. Names, cues, } 80 \text { - } 20 \text { Rule, Fix the leaks, } \\
\text { pinpointing, positive-corrective feedback 3:1 ratio; equitable feedback; } \\
\text { desists, back to wall, promotion of MVPA }\end{array}$ \\
\hline 9 & $\begin{array}{l}\text { May } \\
2015\end{array}$ & $\begin{array}{l}\text { Closure Visit Year One } \\
\text { Feedback on year one; input for planning year two }\end{array}$ \\
\hline 10 & $\begin{array}{c}\text { Year } \\
2\end{array}$ & $\begin{array}{l}\text { Focus on Assessment [Category 7] } \\
\text { Instructional alignment, goals, tasks, assessment of student learning }\end{array}$ \\
\hline 11 & $\begin{array}{c}\text { Year } \\
2\end{array}$ & $\begin{array}{l}\text { Focus on Advocacy [Category 8] } \\
\text { Advocating for quality PE; PE mandates (i.e., time, content, class size, } \\
\text { funding, facilities and other factors that influence quality). }\end{array}$ \\
\hline
\end{tabular}

\section{PRINCIPAL VISITS}

\begin{tabular}{ccc}
\hline Sept-Oct & Quality physical education \\
2014 & Why is quality PE important? What does quality PE look and sound like? \\
& How does SPARK curriculum and SECPEA support quality PE? \\
& Recognizing indicators of quality physical education \\
& What are indicators of physical education program quality? \\
& What observable strategies are common in a quality PE program? \\
2014 & $\begin{array}{l}\text { How do these observable strategies apply in the teacher evaluation process? } \\
\text { Review video examples on the SPARK BASICS: } \\
\text { a) boundaries; b) ASAP; c) signals; d) inclusion; e) clear instruction; } \\
\text { and f) safety and supervision. }\end{array}$
\end{tabular}




\section{Continued}

\begin{tabular}{|c|c|c|}
\hline & & Understanding mandates for quality physical education \\
\hline 3 & $\begin{array}{c}\text { Feb-Mar } \\
2015\end{array}$ & $\begin{array}{l}\text { How many minutes of PE are recommended? Does school meet } \\
\text { recommendations? What factors negatively and positively impact } \\
\text { the quality and quantity of PE? }\end{array}$ \\
\hline 4 & $\begin{array}{c}\text { Apr-May } \\
2015\end{array}$ & $\begin{array}{l}\text { Creating a quality physical education action plan for your school } \\
\text { What factors influence quality in PE? Are there opportunities to } \\
\text { make improvements for next year? } \\
\text { What action steps need to happen to improve the quality of PE next year? }\end{array}$ \\
\hline
\end{tabular}

target student and the lesson context influencing the majority of the students in the class are recorded at the "record" prompt. If the teacher promotes MVPA at any time during the 10 -second observation period it is recorded.

SOFIT allows for estimation of energy expenditure per minute $(\mathrm{kcal} / \mathrm{kg} / \mathrm{min})$ and per lesson ( $\mathrm{kcal} / \mathrm{kg} / \mathrm{lesson}$ ) based on the observed physical activity levels (i.e., lying, sitting, standing, walking, vigorous). The estimated Energy Expenditure Rate (EER $\mathrm{kcal} / \mathrm{kg} / \mathrm{min}$ ) and estimated Total Energy Expenditure (TEE; $\mathrm{kcal} / \mathrm{kg} / \mathrm{lesson}$ ) are derived using estimated values determined by heart rate (i.e., lying $[0.029 \mathrm{kcal} / \mathrm{kg} / \mathrm{min}]$; sitting $[0.047 \mathrm{kcal} / \mathrm{kg} / \mathrm{min}]$; standing [0.051 $\mathrm{kcal} / \mathrm{kg} / \mathrm{min}$ ]; walking $[0.096 \mathrm{kcal} / \mathrm{kg} / \mathrm{min}]$; vigorous $[0.144 \mathrm{kcal} / \mathrm{kg} / \mathrm{min}$ ] McKenzie et al., 1991) Other variables commonly recorded include the start and end time of lessons (i.e., lesson length), lesson location (i.e., indoors, outdoors), number of boys and girls present (i.e., class size), and the apparent gender of each target student observed (i.e., male, female).

\subsubsection{Observation Schedule}

SOFIT observations were scheduled at baseline (Spring 2014), post year one (Spring 2015), and post year two (Spring 2016). Between two and three days of observations were scheduled at least two weeks apart per school. An effort was made to observe different classes and different days of the week and to avoid atypical days (e.g., shortened, modified, or cancelled lessons).

\subsubsection{Observation Training}

Two data collectors were certified prior to the start of data collection at baseline (Spring 2014), post year one (Spring 2015), and post year two (Spring 2016). The standard SOFIT training protocol was followed and trainings were led by a certified trainer. Each of the trainings lasted 2.5 days and included a review of the SOFIT protocol, practice observations using the standard SOFIT training videos, and practice observations with a partner in the field at a local elementary school.

\subsubsection{Reliability}

Reliability was established prior to the start of formal data collection for each observation period (i.e., baseline, post year one, post year two). Once data collectors demonstrated $>85 \%$ accuracy for all three variables by coding the standardized training videos they graduated to practice observations in the field with a partner. Formal data collection began once each observer consistently demon- 
strated $>85 \%$ agreement in field practice trials. Maintenance of reliability was periodically monitored during each observation period (baseline, post year one, and post year two). Reliability observations were conducted for $9.5 \%$ of the total sample ( $\mathrm{n}=50$ out of 529 lessons) and the average reliability exceeded the $85 \%$ standard for physical activity (Mean $=91 \%$; Range $=90 \%-92 \%$ ), lesson context $($ Mean $=96.5 \%$; Range $=96 \%-97 \%)$, and teacher interactions $($ Mean $=92.5 \%$; Range $=90 \%-95 \%)$ respectively

\subsection{Data Collection: Physical Education Teacher Survey}

Physical education teachers completed a brief survey prior to the start of the intervention. The survey was conducted electronically. The purpose was to collect basic information about each teacher in relation to their educational background, years of experience, involvement in professional organizations, current job duties, and overall perceptions about their physical education program.

\subsection{Dependent Variables}

Dependent variables were related to lesson factors (i.e., lesson length [minutes], energy expenditure rate [EER; $\mathrm{kcal} / \mathrm{kg} / \mathrm{min}]$; total energy expenditure [TEE; kcal/kg/lesson]), physical activity (VPA\%; MVPA\%; MVPA\% boys; MVPA\% girls; MVPA\% in 1st 5 minutes; MVPA minutes), lesson contexts (i.e., management $\%$, knowledge $\%$, fitness $\%$, skill practice $\%$, game play $\%$, and free play\%), and teacher interactions (i.e., promotion of MVPA “in" and "out" of physical education).

\subsection{Data Analyses}

All analyses were completed using Statistics Analysis Software (SAS/STAT) Version 9.3 for Windows; Copyright (c) 2002-2010 SAS Institute Inc. The unit of analyses was teacher (i.e., average lesson profile per teacher). The analyses were limited to teachers who completed a survey prior to the start of intervention and were observed (i.e. SOFIT observations) at baseline $(n=21)$, post year one $(n=$ $21)$, and at post year two $(n=16)$.

Means and standard deviations were used to describe continuous variables and percent frequency was used to describe categorical variables of interest. Average lesson profiles were created for teachers during each observation period (i.e., baseline, post year one, post year two). Lesson summaries were created by summing total intervals for all physical activity, lesson context, and teacher promotion of MVPA variables. MVPA was computed by summing moderate and vigorous intervals. Minutes were computed by multiplying the sum for all physical activity and lesson context variables by $1 / 3$. Percentages were computed by dividing the total intervals observed for individual variables by the total intervals observed in the lesson and multiplying by 100. Energy expenditure rate and total energy expenditure were computed using conversion factor estimations for energy cost (i.e., lying [0.029 kcal $/ \mathrm{kg} / \mathrm{min}]$; sitting [0.047 kcal $/ \mathrm{kg} / \mathrm{min}]$; standing $[0.051 \mathrm{kcal} / \mathrm{kg} / \mathrm{min}]$; walking [0.096 kcal $/ \mathrm{kg} / \mathrm{min}]$; vigorous $[0.144$ 
$\mathrm{kcal} / \mathrm{kg} / \mathrm{min}]$, McKenzie et al., 1991).

Linear mixed-model regression analyses and Cohen's $\mathrm{d}$ for dependent samples (Cohen, 1988) assessed the significance (i.e., p value) and magnitude (i.e., effect size) of changes in dependent variables of interest between baseline and post year one, and between post year one and post year two. Teacher was selected as a random effect and observation period was selected as a fixed effect in the regression model. This accounted for repeated measures on teachers and allowed us to include five teachers who were not evaluated at the end of year two. The five teachers without SOFIT data at the end of year two were not included in year one vs year two Cohen's d calculation because Cohen's d requires matched observations (Cohen, 1988). Significance was established at $p<0.05$ and effect sizes (i.e., Cohen's d) were interpreted as 0.2 small, 0.5 medium, and 0.8 large.

\section{Results}

Table 5 presents the results for SOFIT observations at baseline, post year one, and post year two.

A total of 529 lessons were observed. Most lessons were indoors $(72 \% ; n=$ 382). The average class size was 18.0 students per class $(S D=6.6$; Range $=4-56)$ and there were usually more males than females (Mean $=51.3 \%$ boys; $\mathrm{SD}=12.6$; Range $=0 \%-100 \%)$. The average length of lessons was 31.0 minutes $(\mathrm{SD}=9.2$; Range $=16.3-70.0)$. Most lessons $(80 \%)$ were taught to students in classes with a single grade level (e.g., only 1 st graders; $n=422 ; 80 \%$ ).

\subsection{Research Question One}

To what extent did the SECPEA lead to increased MVPA\% and higher quality instruction (i.e., changes in lesson context \% and teacher promotion of MVPA) post year one?

The overall MVPA $\%$ increased moderately by $\Delta+4.6 \%$ (Mean $=60.7 \%$; $\mathrm{SD}=$ $8.2 \% ; p<0.05 ; \mathrm{d}=0.60)$. The most significant increase in MVPA\% was observed during the 1 st 5 minutes of class $(\Delta+17.4 \%$; Mean $=65.3 \%$; $\mathrm{SD}=11.4 \%$; $p<$ $0.01 ; \mathrm{d}=1.52)$. Moderate-large increases were observed in girls MVPA\% $(\Delta+$ 6.3\%; Mean $=59.1 \% ; \mathrm{SD}=8.5 ; p<0.01 ; \mathrm{d}=0.71)$ and moderate increases were observed in teacher promotion of MVPA $(\Delta+6.0 \%$; Mean $=31.0 \%$; $\mathrm{SD}=10.0 ; p$ $<0.05 ; \mathrm{d}=0.47$ ).

Figure 1 shows the percentage of time observed in each lesson context at baseline, post year one, and post year two. Despite consistently positive trends across most lesson contexts, changes were not significant post year one. Management decreased ( $\Delta-1.3 \%$; NS), knowledge increased ( $\Delta+1.1 \%$; NS), fitness increased $(\Delta+5.5 \%$; NS), skill practice was stable (no change; NS), game play decreased $(\Delta-4.0 \%$; NS) and free time was extinguished $(\Delta-0.8 \%$; NS).

\subsection{Research Question Two}

To what extent did the second year of the SECPEA lead to additional changes in $M V P A$, lesson contexts, and teacher promotion of $M V P A$ ? 


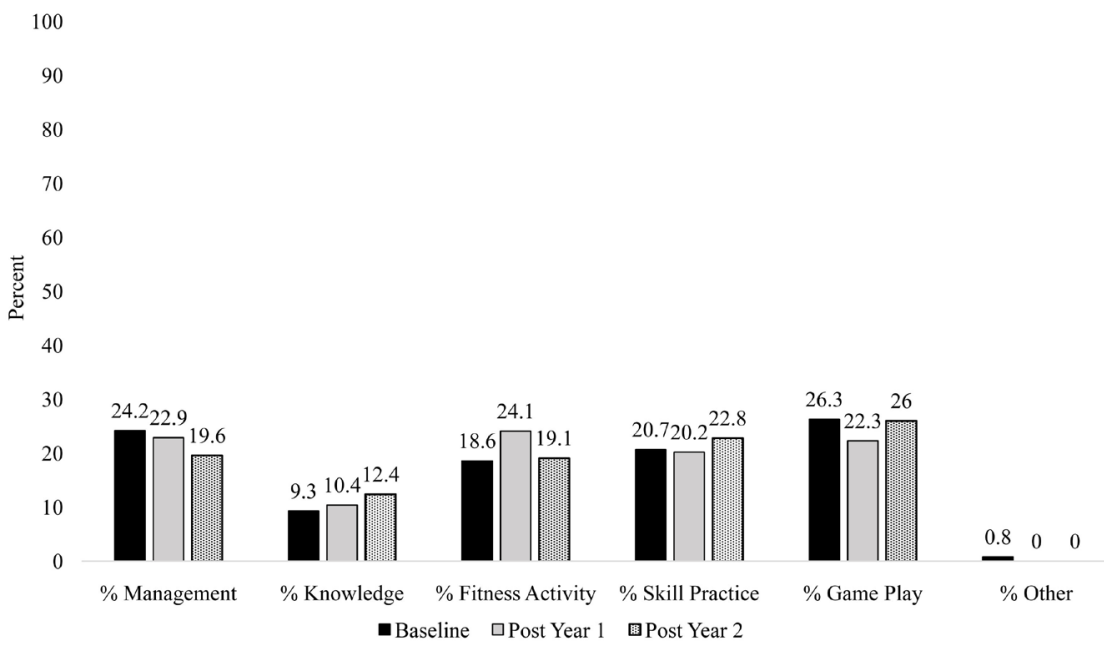

Figure 1. Percentage of time observed in lesson contexts at baseline, post year 1, and post year 2.

Table 5. Select SOFIT lesson characteristics at baseline, year 1 post, and year 2 post.

\begin{tabular}{|c|c|c|c|c|c|c|c|c|}
\hline & \multicolumn{2}{|c|}{$\begin{array}{c}\text { Baseline } \\
21 \text { Teachers } \\
141 \text { lessons }\end{array}$} & \multicolumn{3}{|c|}{$\begin{array}{l}\text { Year } 1 \text { Post } \\
21 \text { Teachers } \\
207 \text { lessons }\end{array}$} & \multicolumn{3}{|c|}{$\begin{array}{c}\text { Year } 2 \text { Post } \\
16 \text { Teachers } \\
181 \text { lessons }\end{array}$} \\
\hline & Mean & SD & Mean $^{\mathrm{h}, \mathrm{i}}$ & SD & $d^{\mathrm{k}, \mathrm{m}}$ & $\operatorname{Mean}^{\mathrm{h}, \mathrm{j}}$ & SD & $d^{1}$ \\
\hline \multicolumn{9}{|l|}{ Lesson Factors } \\
\hline Lesson Length (mins) & 33.0 & 9.7 & 31.7 & 7.4 & -0.29 & 31.5 & 7.4 & -0.26 \\
\hline \multicolumn{9}{|l|}{ Energy Expenditure } \\
\hline EER $\mathrm{kcal} / \mathrm{kg} / \mathrm{min}^{\mathrm{a}}$ & 0.086 & 0.007 & 0.089 & 0.006 & 0.61 & $0.093^{*}$ & 0.009 & 1.06 \\
\hline $\mathrm{TEE}^{\mathrm{b}} \mathrm{kcal} / \mathrm{kg} / \mathrm{lesson}$ & 2.81 & 0.79 & 2.80 & 0.64 & -0.03 & 2.91 & 0.64 & 0.25 \\
\hline \multicolumn{9}{|l|}{ Student Activity } \\
\hline$\% \mathrm{VPA}^{\mathrm{c}}$ & 21.5 & 6.5 & 23.2 & 5.4 & 0.40 & $28.1^{*}$ & 7.5 & 0.68 \\
\hline$\% \mathrm{MVPA}^{\mathrm{d}}$ & 56.1 & 9.1 & $60.7^{*}$ & 8.2 & 0.60 & 64.9 & 11.5 & 1.34 \\
\hline Boys & 59.4 & 9.1 & 62.6 & 8.5 & 0.40 & 66.9 & 11.8 & 1.69 \\
\hline Girls & 52.8 & 10.1 & $59.1^{\star *}$ & 8.5 & 0.71 & 63.0 & 11.5 & 0.87 \\
\hline$\%$ MVPA in 1 st $5 \mathrm{mins}^{\mathrm{e}}$ & 47.9 & 11.6 & $65.3^{* * *}$ & 11.4 & 1.52 & 69.0 & 13.6 & 0.57 \\
\hline MVPA (mins) ${ }^{\mathrm{f}}$ & 18.3 & 5.1 & 19.1 & 4.9 & 0.29 & 20.3 & 5.4 & 0.79 \\
\hline \multicolumn{9}{|l|}{ Lesson Contexts } \\
\hline$\%$ Management & 24.2 & 7.7 & 22.9 & 10.6 & -0.15 & 19.6 & 8.2 & -0.54 \\
\hline$\%$ Knowledge & 9.3 & 5.7 & 10.4 & 6.8 & 0.18 & 12.4 & 7.2 & 0.46 \\
\hline$\%$ Fitness & 18.6 & 10.6 & 24.1 & 12.7 & 0.36 & 19.1 & 11.2 & -0.48 \\
\hline$\%$ Skill practice & 20.7 & 16.1 & 20.2 & 14.9 & -0.04 & 22.8 & 15.9 & 0.11 \\
\hline$\%$ Game play & 26.3 & 23.2 & 22.3 & 18.6 & -0.32 & 26.0 & 12.0 & 0.26 \\
\hline$\%$ Free play & 0.8 & 3.5 & 0.0 & 0.0 & - & 0.0 & 0.0 & - \\
\hline \multicolumn{9}{|l|}{ Teacher Interactions } \\
\hline$\%$ Promotion of MVPA ${ }^{g}$ & 25.0 & 10.1 & $31.0^{*}$ & 10.0 & 0.47 & 33.5 & 12.0 & 0.32 \\
\hline
\end{tabular}

Note. ${ }^{a}$ estimated Energy Expenditure Rate per minute; ${ }^{b}$ estimated Total Energy Expenditure per lesson;

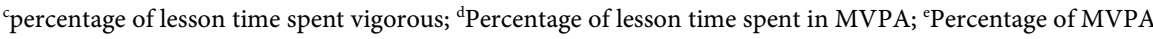
in the $1^{\text {st }} 5$ minutes of class; ${ }^{\mathrm{f}}$ Total MVPA minutes per lesson; ${ }^{\mathrm{g}} \mathrm{Percentage}$ of total lesson intervals that promotion of MVPA in and out of class was observed; ${ }^{\text {h* }} p<0.05,{ }^{* *} p<0.01,{ }^{* * *} p<0.001$; ${ }^{\mathrm{i}}$ Asterisks in the Year 1 Post column compare baseline to year 1 post; ${ }^{j}$ asterisks in the Year 2 Post column compare year 1 post to year 2 post; ${ }^{\mathrm{k}} \mathrm{Effect}$ size Cohen $d(d)$ under Year 1 Post compare baseline to year 1 post; ${ }^{1} \mathrm{~d}$ under Year 2 Post compare year 1 post to year 2 post; ${ }^{\mathrm{m}}$ five teachers without SOFIT data post year two were not included. 
Moderate-large increases were observed in vigorous physical activity (VPA\%; $\Delta+4.9 \% ;$ Mean $=28.1 ; \mathrm{SD}=7.5 ; p<0.05 ; \mathrm{d}=0.68)$ and coincided with a large increase in EER $(\Delta+0.004 ;$ Mean $=0.093 ; \mathrm{SD}=0.009 ; p<0.05 ; \mathrm{d}=1.06)$. There were no other statistically significant changes related to physical activity; however, several positive trends were apparent. Figure 2 shows the results for VPA\% and MVPA\% at baseline, post year one, and post year two. Although the changes were not significant, MVPA\% increased again by nearly $5 \%(\Delta+4.9 \%$; NS); boys' MVPA\% increased $(\Delta+4.3 \%$; NS); girls' MVPA increased $(\Delta+3.9 \%$; NS), MVPA\% in the 1st 5 minutes increased $(\Delta+3.7 \%$; NS) post year two. Two other positive trends are apparent in Table 5: MVPA minutes increased $(\Delta+1.2 \%$; NS) and TEE increased $(\Delta+0.11 \%$; NS).

Similar to post year one, positive, but insignificant trends were also observed for lesson contexts (Figure 1). Management time continued to decrease $(\Delta-$ $3.2 \%$; NS), knowledge time continued to increase $(\Delta+2.0 \%$; NS), skill practice increased $(\Delta+2.6 \%$; NS), and free play was not observed (no change; NS) post year two.

\section{Discussion}

For more than 20 years researchers have attempted to develop effective interventions for increasing health-enhancing MVPA in school environments, and while several EPE programs have demonstrated effectiveness (Lonsdale et al., 2013), models for successful dissemination are needed, especially in undeserved rural schools. It is important to test models in a variety of settings in order to learn more about how to effectively disseminate and implement EPE. Our goal was to implement the PE Academy in 19 schools with 21 teachers in a large rural region of Southeast Colorado (i.e., the SECPEA). We elaborate on the potential of the PE Academy model, describe modifications related to site support, and suggest implications of the results for future efforts to disseminate EPE programs in the discussion.

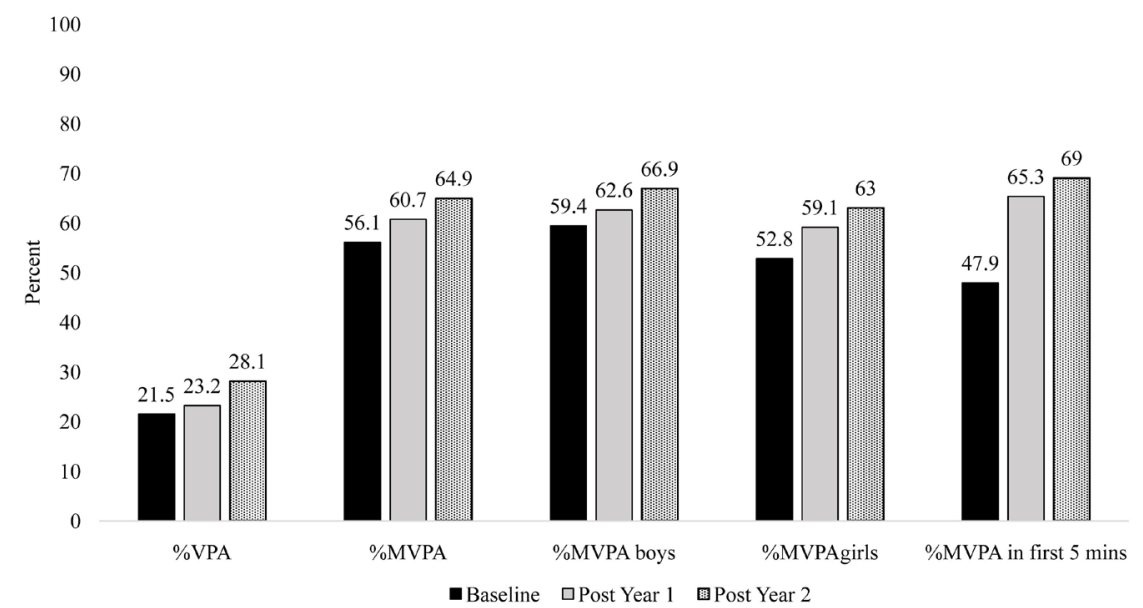

Figure 2. Change in vigorous and moderate-vigorous physical activity at baseline, post year 1 , and post year 2 . 


\subsection{The Potential of the PE Academy Model}

There is evidence that the PE Academy model is effective for increasing health-enhancing MVPA. In the SECPEA, MVPA\% and VPA\% increased significantly in years one and two respectively (Table 5). By the end of year two, students engaged in MVPA\% for nearly $65 \%$ of lesson time including $28.1 \%$ VPA. They accumulated more than 20 minutes of MVPA, one-third of the daily MVPA recommendation. These results are promising and illustrate why EPEs are essential.

The results from the SECPEA compare favorably with other U.S. studies. Students in both Academies accumulated similar amounts of MVPA (20.3 minutes SECPEA vs 21.5 minutes SLVPEA). Overall MVPA\% increased in both Academies $(\Delta+8.8$ MVPA\% SECPEA vs $\Delta+16.2$ MVPA\% SLVPEA), but was nearly twofold greater in the SLVPEA (i.e., Belansky et al., 2016). The MVPA outcomes of both Academies are higher than other interventions in elementary school physical education which reported between 50\% - 53\% MVPA at outcome (Lonsdale et al., 2013). These findings suggest that efforts to replicate the PE Academy model would be worthwhile.

Teachers attempted to change their instructional practices by applying lessons learned from professional development workshops and site support visits. MVPA\% increased $\Delta+21.1 \%$ during the first five minutes of lessons overall (Table 5$)$, slightly less than the SLVPEA $(\Delta+22.6 \%)$. Together these results illustrate that the PE Academy model has been highly successful in motivating teachers to change their practices at the start of lessons. The increases imply that teachers were engaging students in "activity as soon as possible" (ASAP), dynamic warm-up, and/or using high activity management strategies, although the SOFIT data fall short of identifying specific strategies that were employed, and we did not analyze MVPA during lesson contexts. There is also evidence that the learning environment was becoming more supportive of MVPA. Girls' MVPA\% and teacher promotion of MVPA increased in year one (Table 5). The significant increases in VPA\% and EER post year two (Table 5) imply that teachers were improving lesson design and engaging students in activities with greater potential to improve fitness longer-term, although it is unclear if fitness was disguised (e.g., fun activities vs. running laps).

There was weaker evidence that the SECPEA inspired significant and sizable changes in how time was spent in lesson contexts (Figure 1) although the positive trends imply a greater emphasis on fitness and it appears that teachers were more prepared and used time more efficiently. However, in comparison, the SLVPEA resulted in a greater number of statistically significant changes in lesson context time (e.g., less free play, more skill practice, less management; Belansky et al., 2016).

\subsection{Site Support Modifications}

Like the San Luis Valley Physical Education Academy, the SECPEA brought an 
evidence-based physical education curriculum along with equipment, professional development workshops, and tailored site support to a different rural setting. Both Academies sought to achieve similar outcomes (i.e., increases in MVPA\%, changes in lesson context \% and increases in teacher promotion of MVPA) by implementing the same components (i.e., SPARK curricular resources, equipment, professional development workshops, and site support) and using the same observation tool to assess outcomes. However, there was a substantial difference between the delivery of the SECPEA and the SLVPEA, particularly related to site support (e.g., tailoring of site support in the SECPEA, scope and sequence of visits) which we elaborate on below.

Table 6 compares the SECPEA and the SLVPEA interventions (i.e., scale, personnel, adoption process, and intervention components). Decisions related to the delivery of the site support component were largely influenced by the size of the region and logistics related to the coordination and expertise of personnel (e.g., proximity and familiarity with teachers in the region). Table 6 illustrates that the SECPEA region was nearly twice as large as the SLVPEA region $(41,352$ $\mathrm{km}^{2}$ vs. $21,207 \mathrm{~km}^{2}$ ), but the intervention was administered with fewer personnel (i.e., no project manager and only one master teacher in year two). The exact implications of modifying site support are not precisely clear; however, arguably, modifications played a role in shaping the outcomes of the SECPEA and the lessons learned have implications for future interventions and iterations of the PE Academy.

Challenges emerged with staffing over the two-year project that undoubtedly influenced delivery of the site support component. One master teacher was a veteran teacher from the northeast region of Colorado. The other master teacher was less experienced, but had closer proximity to the region. The travel demands were high in year one given the size of the region and lack of master teacher proximity to schools. At the end of year one, one of the master teachers returned to his teaching position in northeast Colorado due to the end of his one-year leave of absence, the other master teacher moved away from the area when his spouse obtained a job elsewhere, and the project manager took a position in an educational foundation out of state. In year two, a new master teacher was hired from the region, but site support was scaled back considerably to make the workload more feasible for him. The project manager wasn't replaced and one of the principal investigators took on those responsibilities. This new configuration of personnel resulted in modifications to the scope and sequence of the site support component.

Three modifications to the SECPEA in year one likely influenced the smaller magnitude and number of significant changes in comparison to the SLVPEA. First, more time was dedicated to relationship building at the start of the intervention because, unlike in the SLVPEA, the master teachers were unfamiliar with most teachers and schools in the region. This may have delayed teacher progress in year one and may explain why there were fewer significant changes post year one because master teachers did not attempt to intervene on practices 
Table 6. Side-by side comparison of SECPEA and SLVPEA.

\begin{tabular}{|c|c|c|c|}
\hline & Description & SECPEA & SLVPEA $^{\mathrm{a}}$ \\
\hline \multicolumn{4}{|l|}{ SCALE } \\
\hline $\begin{array}{l}\text { Region } \\
\text { Size }\end{array}$ & $\begin{array}{l}\text { Schools were located within counties located in large rural regions. } \\
\text { The region size is defined here as the square miles covered by the } \\
\text { counties in which the schools were located, the number of schools, } \\
\text { and the number of districts represented }\end{array}$ & $\begin{array}{l}\text { Southeast Colorado } \\
\text { Eight counties } \\
41,352 \mathrm{~km}^{2} \\
21 \text { schools } \\
19 \text { school districts }\end{array}$ & $\begin{array}{l}\text { San Luis Valley } \\
\text { Six counties } \\
21,207 \mathrm{~km}^{2} \\
17 \text { elementary schools } \\
14 \text { school districts }\end{array}$ \\
\hline \multicolumn{4}{|l|}{ PERSONNEL } \\
\hline $\begin{array}{l}\text { Project } \\
\text { Manager }\end{array}$ & Responsible for supervision of master teachers & $\begin{array}{l}\text { Full-time } \\
\text { Year } 1 \text { only }\end{array}$ & $\begin{array}{l}\text { Full-time } \\
\text { Years } 1 \text { - } 2\end{array}$ \\
\hline $\begin{array}{l}\text { Master } \\
\text { Teachers }\end{array}$ & $\begin{array}{l}\text { Responsible for providing site support to principals } \\
\text { and physical education teachers }\end{array}$ & $\begin{array}{l}\text { Year } 1 \\
1 \text { of } 2 \text { master teachers } \\
\text { not from the region } \\
\text { Year } 2 \\
1 \text { master teacher from } \\
\text { the region }\end{array}$ & $\begin{array}{l}\text { Years } 1-2 \\
2 \text { master teachers from } \\
\text { the region }\end{array}$ \\
\hline
\end{tabular}

\section{ADOPTION}

Recruiting Increasing awareness about HELM and the PE Academy with participants the intent of recruiting participant
Email and phone calls to principals and physical education teachers
Half-day face-to-face session ("happy visits") for principals and physical educators

\section{INTERVENTION COMPONENT}

\begin{tabular}{|c|c|c|c|}
\hline SPARK & SPARK K-2 and 3 - 6 Folios SPARK & & \\
\hline Curriculum & Family access @ \$399 per Folio & & \\
\hline & Equipment to implement the full curriculum & $\$ 9,936$ per school & $\$ 3,953$ per school \\
\hline Equipment & $\begin{array}{l}\text { Tailored for each school based on largest class size up } \\
\text { to limit of } 36 \text { students. }\end{array}$ & & \\
\hline $\begin{array}{l}\text { Professional } \\
\text { Development }\end{array}$ & Four SPARK two-day workshops led by Elite SPARK trainer & $\begin{array}{l}8 \text { total days } \\
64 \text { hours }\end{array}$ & $\begin{array}{l}8 \text { total days } \\
64 \text { hours }\end{array}$ \\
\hline Workshops & $\begin{array}{l}\text { Two-day booster workshops led by expert teachers from } \\
\text { the first PE Academy }\end{array}$ & $\begin{array}{l}2 \text { days } \\
16 \text { hours }\end{array}$ & $\begin{array}{l}2 \text { total days } \\
16 \text { hours }\end{array}$ \\
\hline $\begin{array}{l}\text { Teacher Site } \\
\text { Support }\end{array}$ & $\begin{array}{l}\text { Master teacher visits to facilitate active teacher participation, } \\
\text { support implementation of SPARK in PE classes, } \\
\text { inspire growth in practices, and engage in peer-peer reflection }\end{array}$ & $\begin{array}{l}10-14 \text { visits per teacher } \\
8-9 \text { visits year one } \\
2 \text { - } 5 \text { visits year two } \\
\text { Tailored after } 5 \text { visits }\end{array}$ & $\begin{array}{l}19 \text { visits per teacher } \\
11 \text { visits year one } \\
8 \text { visits year two } \\
\text { Tailored after } 11 \text { visits }\end{array}$ \\
\hline Site & Master teacher visits to increase principals' knowledge, & 4 meetings in year one & 6 meetings over two years \\
\hline Support & self-efficacy, outcome expectations, and skills for & $\sim 60$ minutes each & $\sim 60$ minutes each \\
\hline Principals & supporting a high quality physical education programs & $\sim 240$ total minutes & $\sim 360$ total minutes \\
\hline
\end{tabular}

Note: aBelansky et al., 2016.

until later in fall of 2014. Second, master teachers adopted the tailored approach in the second half of year one and thus had greater flexibility in making choices on the topics that would be covered. They could slow down or speed up depending on the performance and goals of the teacher. This introduced variability in the focus of site support visits between teachers. Third, the site support component was scaled down resulting in fewer site support visits in years one and two. 
The modifications to site support resulted in changes to the scope and sequence of content in meetings with teachers and principals and altered how each category of the rubric for "high quality physical education" was addressed in the intervention. The SLVPEA teachers received site support on each category of the rubric systematically but the SECPEA teachers received less exposure to the rubric and the site support intervention due to the scaling back of site support in year two. The SLVPEA did not use a tailored approach until after all teachers had received 11 visits in year one. As a result, there was much greater consistency in the site support provided to teachers in the SLVPEA compared to those in the SECPEA.

Some modifications in site support were also attributed to challenges with coordinating master teacher and physical education teacher schedules. As shown in Table 1, teachers in the SECPEA spent an average of 54\% of their day teaching physical education ( $\mathrm{SD}=27.4 \%$ ), were responsible for an average of $3.0 \mathrm{du}$ ties $(\mathrm{SD}=0.9)$ including teaching physical education, and taught $6-7$ grade levels in physical education ( $\mathrm{SD}=3.2$ ). These data illustrate how busy some teachers were and have implications for the amount of time teachers had to prepare. In some cases, teachers mentioned it was difficult to balance all their duties while also being responsible for engaging in the SECPEA and attempting to make changes to their physical education program and practices.

\subsection{Implications for Future Dissemination Efforts}

This study demonstrates that the PE Academy model has been successful in a second and very different rural region. This study's results have important implications for future efforts to disseminate and implement EPE programs. Perhaps most importantly, the PE Academy model is effective in increasing MVPA and VPA in physical education; thus, future efforts should consider replicating the model nationwide using a dissemination and implementation framework such as the Consolidated Framework for Implementation Research to identify the contextual factors that facilitate or inhibit successful outcomes (Damschroder et al., 2009). Further, given the fact that Academy schools accumulated about one-third of the daily requirement for MVPA in physical education, it is easy to make a case for expanding elements of the model to target other physical activity opportunities in the school day (e.g., classroom brain boosters, recess, before, and after-school opportunities). If future efforts include other physical activity opportunities, support from classroom teachers and principals will be important in order to maximize MVPA outcomes beyond physical education. This would be a worthwhile investment given the benefits associated with regular participation and meeting guidelines for MVPA (e.g., healthy growth and development and academic achievement).

The study's results also have implications for providing site support and professional development to physical education teachers. It appears that modifications to site support in terms of the number of visits and modifications to the 
scope and sequence influenced the weaker results related to lesson contexts. Future studies are needed to determine the effectiveness and dose-response of the site support component with attention given to content analysis and revision of the site support scope and sequence. It does not appear that tailoring was effective in the SECPEA, and in consideration of the effectiveness of the SLVPEA, the results suggest that it may be more effective for master teachers to deliver site support uniformly while they build their own skills. Perhaps tailored approaches to site support can be more successful once master teachers have greater mastery in their role and once relationships with teachers are more firmly established.

\subsection{Limitations}

The results of this study were limited to the observations of 21 teachers from 19 small remote rural schools and may not generalize to other settings. Observations were limited to what data collectors could see and hear. We did not conduct analyses of how active students were during each lesson context. This limited our ability to know precisely how teacher practices changed when students were engaged in MVPA and VPA (e.g., first five minutes of lessons). The lack of significant findings may have been influenced by lack of statistical power due to attrition of five teachers post year two. There was a ceiling effect for MVPA\% at baseline which was much greater than the 36\% - 37\% MVPA commonly reported in studies of elementary physical education (McKenzie et al., 1995). This ceiling effect may be due to reactivity which is commonly reported as a limitation of observation research. Teachers and students may have reacted to observers by changing their behavior. In this study, it was challenging to employ strategies to minimize reactivity given the large region $\left(41,352 \mathrm{~km}^{2}\right)$ and the ethical obligation to communicate with teachers for scheduling observations). Due to the size of the region and the distance traveled by observers to conduct SOFIT observations teachers knew when SOFIT observers were coming.

\section{Conclusion}

The PE Academy has now demonstrated effectiveness in two different rural settings. The results illustrate the EPE's potential to contribute to public health goals for MVPA (i.e., one third of the daily recommendation). The results also highlight the importance of continuing to study implementation of EPE across a broad range of contexts (e.g., culturally and ethnically diverse settings). Future efforts to replicate the model should consider both place (e.g., size and culture of the region) and implementation strategies (e.g., the expertise and deployment of master PE teachers, the standardization versus tailoring of site support). Lastly, it would be worth conducting studies that use the Consolidated Framework for Implementation Research as a rubric to identify the contextual factors that facilitate and/or inhibit successful dissemination and implementation of EPEs (Damschroder et al., 2009). Findings from those studies will speed up the process of successfully implementing EPEs across diverse settings. 


\section{Acknowledgements}

We acknowledge the contributions of steering committee members who served in an advisory role to the Healthy Eaters, Lifelong Movers project and other state and national consultants including Ben Kern, John Naranjo, Donna Armenta, Terry Jones, and Thom McKenzie. Project staff also played an important role and included Jerry Jones, Shirley Berg, Sharon Scarbro, Ben Ingman, Carla Loecke, Kranti Dugar, Rory Lynch, Mitch McGill, and Larry Gifford. SPARK support was provided by Paul Rosengard, Leticia Gonzalez, Ryan Schissler, Julie Frank, Julie Green, and Joan Gillem. The original SLVPEA rubric was created by Ben Kern and John Naranjo.

\section{Authors' Contributions}

The study was conceptualized by NS and EB. NS was responsible for all aspects of the writing process and manuscript preparation. EB guided study conceptualization, methodology, and assisted with editorial revisions. NC assisted with study conceptualization and editorial revisions. All authors read and reviewed the final version of the manuscript and agree with the order of presentation of the authors.

\section{Funding}

This work was supported by a grant from The Colorado Health Foundation (\#5733).

\section{Availability of Data and Material}

Supplementary data and the rubric for "High Quality Physical Education" are available upon request from the first author.

\section{Conflicts of Interest}

The authors declare no conflicts of interest regarding the publication of this manuscript.

\section{References}

Belansky, E. S., Cutforth, N., Chavez, R., Crane, L. A., Waters, E., \& Marshall, J. A. (2013). Adapted Intervention Mapping: A Strategic Planning Process for Increasing Physical Activity and Healthy Eating Opportunities in Schools via Environment and Policy Change. Journal of School Health, 83, 194-205. https://doi.org/10.1111/josh.12015

Belansky, E. S., Cutforth, N., Kern, B., \& Scarbro, S. (2016). Disseminating Evidence-Based Physical Education Practices in Rural Schools: The San Luis Valley Physical Education Academy. Journal of Physical Activity and Health, 13, 1002-1009. https://doi.org/10.1123/jpah.2015-0467

Cohen, J. E. (1988). Statistical Power Analysis for the Behavioral Sciences (2nd ed.). New York: Lawrence Erlbaum Associates, Publishers.

Community Preventive Services Task Force (2014). Behavioral and Social Approaches to Increase Physical Activity: Enhanced School-Based Physical Education. A Task Force 
Finding and Rationale Statement.

https://www.thecommunityguide.org/sites/default/files/assets/PA-Behavioral-School-b ased-PE.pdf

Damschroder, L. J., Aron, D. C., Keith, R. E., Kirsh, S. R., Alexander, J. A., \& Lowery, J. C. (2009). Fostering Implementation of Health Services Research Findings into Practice: A Consolidated Framework for Advancing Implementation Science. Implementation Science, 4, 40-55. https://doi.org/10.1186/1748-5908-4-50

Gordon-Larsen, P., The, N. S., \& Adair, L. S. (2010). Longitudinal Trends in Obesity in the United States from Adolescence to the Third Decade of Life. Obesity, 18, 1801-1804. https://doi.org/10.1038/oby.2009.451

Hales, C. M., Carroll, M. D., Fryar, C. D., \& Ogden, C. L. (2017). Prevalence of Obesity among Adults and Youth: United States, 2015-2016. NCHS Data Brief No. 288, Hyattsville, MD: National Center for Health Statistics. https://www.cdc.gov/nchs/data/databriefs/db288.pdf

Harringer, J. A., \& Thompson, J. K. (2012). Psychological Consequences of Obesity: Weight Bias and Body Image in Overweight and Obese Youth. International Review of Psychiatry, 24, 247-253. https://doi.org/10.3109/09540261.2012.678817

Housing Assistance Council [HAC] (2012). Taking Stock: Rural People, Poverty, and Housing in the 21st Century. A Report Prepared by the Housing Assistance Council, Washington DC: Cooperative Agreement H-21615 CA; U.S. Department of Housing and Urban Development [HUD].

http://www.ruralhome.org/storage/documents/ts2010/ts_full_report.pdf

IOM Institute of Medicine (2013). Educating the Student Body: Taking Physical Activity and Physical Education to School. Washington DC: The National Academies Press.

Israel, B. A., Coombe, C. M., Cheezum, R. R., Schulz, A. J., McGranaghan, R. J., Lichtenstein, R. et al. (2010). Community-Based Participatory Research: A Capacity Building Approach for Policy Advocacy Aimed at Eliminating Health Disparities. American Journal of Public Health, 100, 2094-2102. https://doi.org/10.2105/AJPH.2009.170506

Johnson, J. A. 3rd, \& Johnson, A. M. (2015). Urban-Rural Differences in Childhood and Adolescent Obesity in the United States: A Systematic Review and Meta-Analysis. Childhood Obesity, 11, 233-241. https://doi.org/10.1089/chi.2014.0085

Lonsdale, C., Rosenkranz, R. R., Peralta, L. R., Bennie, A., Fahey, P., \& Lubans D. R. (2013). A Systematic Review and Meta-Analysis of Interventions Designed to Increase Moderate-to-Vigorous Physical Activity in School Physical Education Lessons. Preventive Medicine, 56, 152-161. https://doi.org/10.1016/j.ypmed.2012.12.004

McKenzie, T. L. (2015). SOFIT: System for Observing Fitness Instruction Time. Description and Procedures Manual. https://activelivingresearch.org/sofit-system-observing-fitness-instruction-time

McKenzie, T. L., \& Smith, N. J. (2017). Studies of Physical Education in the United States Using SOFIT: A Review. Research Quarterly for Exercise \& Sport, 88, 492-502. https://doi.org/10.1080/02701367.2017.1376028

McKenzie, T. L., Alcaraz, J. E., \& Sallis, J. F. (1994). Assessing Children's Liking for Activity Units in an Elementary School Physical Education Curriculum. Journal of Teaching in Physical Education, 13, 206-215. https://doi.org/10.1123/jtpe.13.3.206

McKenzie, T. L., Alcaraz, J. E., Sallis, J. F., \& Faucette, F. N. (1998). Effects of a Physical Education Program on Children's Manipulative Skills. Journal of Teaching in Physical Education, 17, 327-341. https://doi.org/10.1123/jtpe.17.3.327

McKenzie, T. L., Feldman, H., Woods, S. E., Romero, K. A., Dahlstrom, V., Stone, E. J. et 
al. (1995). Children's Activity Levels and Lesson Context during Third-Grade Physical Education. Research Quarterly for Exercise and Sport, 66, 184-193. https://doi.org/10.1080/02701367.1995.10608832

McKenzie, T. L., Sallis, J. F., \& Nader, P. R. (1991). SOFIT: System for Observing Fitness Instruction Time. Journal of Teaching in Physical Education, 11, 195-205. https://doi.org/10.1123/jtpe.11.2.195

McKenzie, T. L., Sallis, J. F., Prochaska, J. J., Conway, T., L., Marshall, S. J., \& Rosengard, P. (2004). Evaluation of a Two-Year Middle-School Physical Education Intervention: M-SPAN. Medicine \& Science in Sports \& Exercise, 36, 1382-1388. https://doi.org/10.1249/01.MSS.0000135792.20358.4D

McKenzie, T. L., Sallis, J. F., Rosengard, P., \& Ballard, K. (2016). The SPARK Programs: A Public Health Model of Physical Education Research and Dissemination. Journal of Teaching in Physical Education, 35, 381-389. https://doi.org/10.1123/jtpe.2016-0100

Prochaska, J. J., Sallis, J. F., Slyman, D. J., \& McKenzie, T. L. (2003). A Longitudinal Study of Children's Enjoyment of Physical Education. Pediatric Exercise Science, 15, 170-178. https://doi.org/10.1123/pes.15.2.170

Sallis, J. F., McKenzie, T. L., Alcaraz, J. E., Kolody, B., Faucette, N., \& Hovell, M. F. (1997). The Effects of a 2-Year Physical Education Program (SPARK) on Physical Activity and Fitness in Elementary School Student. Sports, Play and Active Recreation for Kids. American Journal of Public Health, 87, 1328-1334. https://doi.org/10.2105/AJPH.87.8.1328

Smith, N. J., McKenzie, T. L., \& Hammons, A. J. (2019). International Studies of Physical Education Using SOFIT: A Review. Advances in Physical Education, 9, 53-74. https://doi.org/10.4236/ape.2019.91005

Strauss, R. (2000). Childhood Obesity and Self-Esteem. Pediatrics, 105, 15-22. https://doi.org/10.1542/peds.105.1.e15

United Nations Educational, Scientific and Cultural Organization (UNESCO) (2015). Quality Physical Education: Guidelines for Policy-Makers. Paris: UNESCO. http://unesdoc.unesco.org/images/0023/002311/231101E.pdf

USDHHS U.S. Department of Health and Human Services (2018). Physical Activity Guidelines for Americans (2nd ed.). Washington DC: U.S. Department of Health and Human Services.

https://health.gov/sites/default/files/2019-09/Physical_Activity_Guidelines_2nd_editio $\underline{\text { n.pdf }}$

Ver Ploeg, M., Breneman, V., Dutko, P., Williams, R., Snyder, S., Dicken, C. et al. (2012). Access to Affordable and Nutritious Food: Updated Estimates of Distance to Supermarkets Using 2010 Data, ERR-143. U.S. Department of Agriculture, Economic Research Service.

https://www.ers.usda.gov/webdocs/publications/45032/33845_err143.pdf?v=0

Warren, M., Beck, S., \& Delgado, D. (2019). The State of Obesity: Better Policies for a Healthier America 2019 with Special Feature on Racial and Ethnic Disparities in Obesity and Advancing Health Equity. A Report from Trust for America's Health. https://media.stateofobesity.org/wp-content/uploads/2019/09/16100613/2019ObesityR eportFINAL.pdf

World Health Organization (WHO) (2018a). Fact Sheets Obesity and Overweight. http://www.who.int/news-room/fact-sheets/detail/obesity-and-overweight

World Health Organization (WHO) (2018b). Global Action Plan on Physical Activity 2018-2030: More Active People for a Healthier World (p. 104). Geneva: World Health Organization.

http://apps.who.int/iris/bitstream/handle/10665/272722/9789241514187-eng.pdf 


\section{Abbreviations}

AIM: Assess Identify Make it Happen

EER: Energy Expenditure Rate

EPE: Enhanced Physical Education

HELM: Healthy Eaters, Lifelong Movers

MVPA: Moderate to Vigorous Physical Activity

NS: Not Significant

SECPEA: Southeast Colorado Physical Education Academy

SLVPEA: San Luis Valley Physical Education Academy

SPARK: Sports Play and Active Recreation for Kids

SOFIT: System for Observing Fitness Instruction Time

TEE: Total Energy Expenditure

VPA: Vigorous Physical Activity 